\title{
PENINGKATAN KEMAMPUAN STORYTELLING MELALUI KOLABORASI DIGITAL LEARNING DAN MODEL GUIDED INQUIRY LEARNING
}

\author{
Rini Fadhillah Putri ${ }^{1)}$ \\ Yuda Setiawan ${ }^{2)}$ \\ Fakultas Keguruan Dan Ilmu Pendidikan \\ Universitas Muslim Nusantara Al Washliyah Medan
}

\begin{abstract}
Abstrak
Perkembangan teknologi komputer, informasi dan komunikasi yang berkembang saat ini telah memberikan dampak yang luar biasa bagi kehidupan manusia, termasuk dalam bidang pendidikan. Perkembangan teknologi untuk pendidikan membantu mahasiswa dalam proses pembelajaran. Dengan adanya teknologi memberikan kesempatan kepada mahasiswa lebih inovatif, kreatif, dan aktif sehingga nantinya diharapkan proses pembelajaran menjadi sesuatu yang menyenangkan bagi mahasiswa. Penelitian ini bertujuan untuk mengetahui perbedaan kemampuan storytelling mahasiswa dengan menggunakan modifikasi guided inquiry learning dan digital learning. Penelitian dilaksanakan di UMN Al-washliyah Medan. Populasi yang dijadikan dalam penelitian ini adalah seluruh semester III Pendidikan Bahasa inggris, sehingga sampel diambil secara random purposive sebanyak 30 orang, pada semester III A sebagai kelas kontrol hanya menggunakan model konvensional,semester IIIB sebagai kelas eksperimen dengan kolaborasi model guided inquiry learning dan digital learning. Terlebih dahulu data di analisis uji normalitas dan uji homogenitas data dengan syarat sig > 0,05, maka diketahui bahwa data berdistribusi normal dan homogen, kemudian data hasil kemampuan storytelling dianalisis dengan menggunakan General Linier Models, dengan syarat penerimaan hipotesis adalah sig < 0,05 dan dalam proses pembelajaran mahasiswa lebih aktif dan keadaan kelas lebih nyaman dan kondusif.
\end{abstract}

Kata kunci: model pembelajaran inkuiri terpandu, pembelajaran digital, kemampuan bercerita

\begin{abstract}
The development of computer technology, information and communication that developed today has given tremendous impact to human life, including in the field education. The development of technology for education helps students in the process learning. The technology provides more opportunities for students to be innovative, creative, and active so that later expected learning process into something fun for students. This study aims to determine the differences students' storytelling skills by using the modified guided inquiry learning and digital learning. The research was conducted at UMN Al-Washliyah Medan. Population used in the study this is the entire third semester English Education, so the samples are taken on a regular basis random purposive as many as 30 people, in the third semester $A$ as the control class only using conventional model, semester IIIB as experiment class with collaboration model guided inquiry learning and digital learning. First the data in the test analysis normality and homogeneity test data with sig > 0,05, hence known that data distributed normal and homogeneous, then the data result of storytelling ability is analyzed by using General Linear Models, provided that acceptance of hypothesis issig<0.05 and in the student learning process more active,comfortable and
\end{abstract}


conducive.

Keywords: guided inquiry learning model, digital learning, storytelling ability.

\section{PENDAHULUAN}

\subsection{Latar Belakang Masalah}

Perkembangan teknologi di era modern sangat membantu proses pembelajaran menjadi pembelajaran yang inovatif. Pembelajaran yang inovatif akan mendorong mahasiswa untuk berfikir kreatif, artinya semakin inovatif pembelajaran yang terjadi di dalam kelas, maka semakin mudah kompetensi materi tersampaikan. Pembelajaran yang inovatif ditandai dengan media, media digunakan sebagai perantara penyelesaian masalah. Media pembelajaran akan membantu setiap kegiatan pada proses penyampaian dalam pembelajaran menjadi mudah dan menyenangkan. Penggunaan media digital lebih menarik dibandingkan dengan media konvensional, karena dalam digital learning, pembelajaran menggunakan software sehingga tampilan menjadi lebih menarik dan mendorong mahasiswa untuk berfikir kreatif.

Salah satu manfaat digital learning bisa diaplikasikan untuk meningkatkan kemampuan storytelling mahasiswa. Berdasarkan hasil observasi selama mengajar, mahasiswa mengalami kesulitan dalam menceritakan sebuah gambar. Mahasiswa kesulitan menemukan ide untuk diceritakan. Hal ini juga ditegaskan melalui wawancara dari beberapa mahasiswa yang mengalami kesulitan untuk mengemukakan ide mereka dikarenakan metode yang digunakan tidak menarik dan tidak adanya arahan dari dosen yang bersangkutan.

Dengan memodifikasikan guided inquiry, mahasiswa akan dibimbing untuk menemukan ide mereka dan diberikan kesempatan untuk mengemukakannya, kemudian dengan bantuan digital learning, mahasiswa diberi kesempatan untuk berkreasi melalui software yang bertujuan untuk menyampaikan ide mereka. Dengan digital learning akan memberikan proses berfikir menjadi lebih menarik dengan mengunduh foto atau gambar, kemudian mahasiswa akan menceritakan isi yang terkandung dalam gambar tersebut.

Dengan menggunakan modifikasi pembelajaran ini, akan memotivasi mahasiswa untuk berfikir kreatif, bahkan membangkitkan motivasi untuk belajar bercerita dan memberikan kesempatan mahasiswa berkreasi semaksimal mungkin.

\subsection{Tujuan Penelitian}

Sesuai rumusan masalah, maka dapat diketahui tujuan penelitian sebagai berikut:

1. Untuk mengetahui ada pengaruh model guide inquiry learning dalam meningkatkan kemampuan storytelling mahasiswa

2. Untuk mengetahui ada pengaruh digital learning dalam meningkatkan kemampuan storytelling mahasiswa

3. Untuk mengetahui ada interaksi 
modifikasi model guide inquiry learning dan digital learning dalam meningkatkan kemampuan storytelling mahasiswa

\section{METODE}

Tempat penelitian di UMN AlWashliyah Medan. Waktu kegiatan penelitian dimulai dari Agustus Desember 2017 dengan populasi yang dijadikan dalam penelitian ini adalah seluruh semester III Pendidikan Bahasa Inggris, sehingga sampel diambil secara random purposive, maka dapat diambil dua kelas dimana satu kelas menjadi kelas eksperimen dengan menggunakan kolaborasi model guided inquiry learning dan digital learning dan satu kelas menjadi kelas kontrol dengan menggunakan metode konvensional, masingmasing diambil sebanyak 30 peserta didik.

Metode penelitian ini adalah eksperimen (kuantitatif) yaitu metode penelitian yang berlandaskan pada filsafat positivisme, digunakan untuk meneliti pada populasi atau sampel tertentu. Desain penelitian ini adalah desain faktorial yang

\begin{tabular}{lccc}
\hline & $\mathrm{SP} \longrightarrow$ & \multicolumn{2}{c}{ Model Pembelajaran $(\mathrm{X})$} \\
\hline $\mathrm{SE}$ & & $\begin{array}{c}\text { Guided Inquiry } \\
\text { Learning dan } \\
\text { Digital Learning }\end{array}$ & $\begin{array}{c}\text { Konvensional } \\
\left(\mathrm{X}_{1}\right)\end{array}$ \\
& $\mathrm{X}$ & $\mathrm{X}_{2} \mathrm{Y}$ & \\
$\begin{array}{l}\text { Kemampuan } \\
\text { Storytelling }(\mathrm{Y})\end{array}$ & $\mathrm{Y}$ & $\mathrm{X}_{2} \mathrm{Y}$ \\
\hline
\end{tabular}

merupakan modifikasai dari design true experimental dimana memperhatikan kemungkinan variabel moderator yang mempengaruhi perlakuan (independent variabel) terhadap kemampuan storytelling (dependent variable). Dimana penelitian ini terdapat tiga variabel penelitian yaitu dua independent variabel dan satu dependent variabel. Sebagai independent variabel model guided inquiry learning dan digital learning serta dependent variabel (output) yaitu kemampuan storytelling dibagi menjadi dua yaitu kemampuan storytelling kelas eksperimen dan kemampuan storytelling kelas kontrol. Independent variabel dijadikan sebagai variabel perlakuan dan variabel moderator (Sugiyono, 2009:113).

Variabel perlakuan dibedakan menjadi dua, yaitu kolaborasi strategi model guided inquiry learning dan digital learning $\left(\mathrm{X}_{1}\right)$ untuk kelompok eksperimen dan metode konvensional untuk kelompok krontrol $\left(\mathrm{X}_{2}\right)$. Dengan rancangan faktorial $2 \times 2$ adalah sebagai berikut:
Berdasarkan desain penelitian diatas, maka penelitian ini akan dilakukan uji normalitas (one sample Kolmogorov Smirnov) dan homogenitas data (One way Anova), setelah itu akan dilanjutkan dengan uji hipotesis dengan menggunakan analisis varians dua jalur (Genera lLinier Models), dengan menggunakan analisis ini maka dapat menunjukkan adanya interaksi sesuai hipotesis deskriptif dengan menggunakan SPSS 22 for Windows maka analisis dilanjutkan dengan uji 
Two Ways. Membandingkan harga Sig hasil perhitungan dengan SPSS 22 for Windows, dengan cara untuk uji normalitas dan homogenitas diterima jika sig > 0,05 maka data dinyatakan berdistribusi normal dan homogen, sedangkan uji hipotesis diterima jika sig < 0,05.

\section{HASIL DAN PEMBAHASAN}

Penelitian ini dilaksanakan dua kelas, diantaranya kelas eksperimen dan kelas kontrol. Diketahui bahwa hasil kemampuan storytelling mahasiswa kelas eksperimen lebih baik dibandingkan kelas kontrol, hasil kemampuann storytelling terlihat jelas pada gambar dibawah ini:

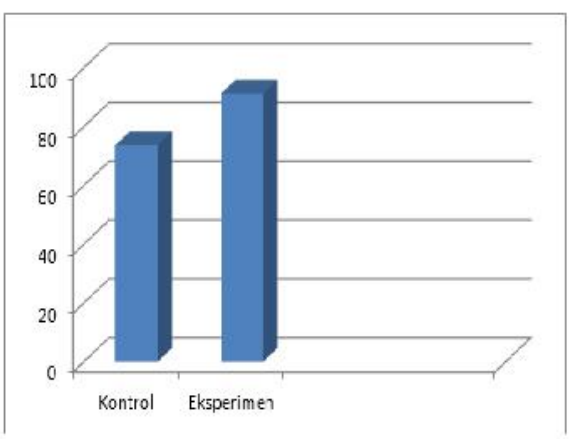

Gambar. Grafik Batang Rata-Rata Hasil Kemampuan Storytelling Mahasiswra

Uji normalitas bertujuan untuk mengetahui apakah analisis antara variabel dependen dan variabel independen mempunyai distribusi normal. Normalitas merupakan pengujian, apakah dalam sebuah model regresi, variabel dependen, variabel independen atau keduanya mempunyai distribusi normal atau tidak. Model regresi yang baik adalah distribusi datanya normal atau mendekati normal. Untuk menguji normalitas dalam penelitian ini dengan menggunakan uji kolmogorov-smirnov.

Tabel 1 Uji Normalitas

One-Sample Kolmogorov-Smirnov Test

\begin{tabular}{|c|c|c|}
\hline & & $\begin{array}{l}\text { Unstandardiz } \\
\text { ed Residual } \\
\end{array}$ \\
\hline $\mathrm{N}$ & & 30 \\
\hline & Mean &, 0000000 \\
\hline Normal Parameters & Std. & 339187590 \\
\hline & Deviation & (2,3910/790 \\
\hline Most Fxtreme & Absolute &, 150 \\
\hline Nost Exureme & Positive &, 075 \\
\hline Dinerences & Negative &,- 150 \\
\hline Test Statis & &, 150 \\
\hline Asymp. Sig. (2 & iled) &, $082^{\mathrm{c}}$ \\
\hline
\end{tabular}

a. Test distribution is Normal.

b. Calculated from data.

c. Lilliefors Significance Correction.

Berdasarkan tabel 1 diatas, model regresi dinyatakan normal, hal ini dikarenakan nilai signifikansinya lebih besar dari 0,05. Maka data dapat dinyatakan berdistribusi normal.

Selanjutnya dilakukan uji homogenitas data, hal ini juga di tunjukkan pada tabel.2., yang menyatakan sig > 0,05 dengan demikian data homogen serta dinyatakan juga sampel penelitian homogen.

Tabel 2 Uji Homogenitas

Levene's Test of Equality of Error Variances ${ }^{a}$

Dependent Variable: Story Telling

\begin{tabular}{|c|c|c|c|}
\hline F & df1 & df2 & Sig. \\
\hline 10,525 & 17 & 12 &, 000 \\
\hline
\end{tabular}
Tests the null hypothesis that the error
variance of the dependent variable is
equal across groups.

a. Design: Intercept + PreTest + PostTest

+ PreTest * PostTest

\section{Tabel 2 Uji Homogenitas}

Dengan diketahui uji awal tersebut, maka dapat dilanjuti uji untuk hipotesis dengan menggunakan jalur ANAVA dengan 
menggunakan analisa SPSS 22 for windows. Dalam hal dilakukan dengan syarat sig $<0,05$. Hal ini akan diperlihatkan pada tabel 3 sebagai berikut:

Tabel 3 Uji General Linier Model pada uji Hipotesis Tests of Between-Subjects Effects

Dependent Variable: Story Telling

\begin{tabular}{|l|r|r|r|r|r|}
\hline Source & $\begin{array}{c}\text { Type III Sum } \\
\text { of Squares }\end{array}$ & df & Mean Square & \multicolumn{1}{c|}{ F } & Sig. \\
\hline Corrected Model & $238,300^{\mathrm{a}}$ & 17 & 14,018 & 1,244 &, 356 \\
Intercept & 68961,836 & 1 & 68961,836 & 6122,382 &, 000 \\
PreTest & 27,959 & 4 & 6,990 &, 621 &, 657 \\
PostTest & 97,723 & 6 & 16,287 & 1,446 &, 276 \\
PreTest * & 92,044 & 6 & 15,341 & 1,362 &, 305 \\
PostTest & 135,167 & 12 & 11,264 & & \\
Error & 110302,000 & 30 & & & \\
Total & 373,467 & 29 & & & \\
Corrected Total & & & & \\
\hline
\end{tabular}

a. $\mathrm{R}$ Squared $=, 638$ (Adjusted $\mathrm{R}$ Squared $=, 125$ )

\begin{tabular}{|l|r|r|r|r|r|}
\hline Source & $\begin{array}{c}\text { Type III Sum } \\
\text { of Squares }\end{array}$ & df & Mean Square & \multicolumn{1}{c|}{ F } & \multicolumn{1}{c|}{ Sig. } \\
\hline Corrected Model & $238,300^{\mathrm{a}}$ & 17 & 14,018 & 1,244 &, 356 \\
Intercept & 68961,836 & 1 & 68961,836 & 6122,382 &, 000 \\
PreTest & 27,959 & 4 & 6,990 &, 621 &, 657 \\
PostTest & 97,723 & 6 & 16,287 & 1,446 &, 276 \\
PreTest* & 92,044 & 6 & 15,341 & 1,362 &, 305 \\
PostTest & 135,167 & 12 & 11,264 & & \\
Error & 110302,000 & 30 & & & \\
Total & 373,467 & 29 & & & \\
Corrected Total & & & & \\
\hline
\end{tabular}

a. R Squared = ,638 (Adjusted R Squared $=, 125$ )

Dengan demikian dari tabel.3 dapat disimpulkan bahwa terdapat perbedaan signifikan kemampuan storytelling mahasiswa, mahasiswa menjadi lebih kreatif dalam menyajikan cerita mereka dan lebih bersemangat untuk menceritakannya kepada teman- teman mereka.

\section{KESIMPULAN}

Dari hasil dan pembahasan, maka dapat disimpulkan sebagai berikut:
1. Terdapat perbedaan hasil kemampuan storytelling mahasiswa yang diberikan model guided inquiry learning dengan nilai rata-rata kelas eksperimen sebesar 91,2 sedangkan kelas kontol hanya 73,73 .

2. Terdapat perbedaan hasil kemampuan storytelling yang diberikan digital learning pada proses pembelajarannya.

3. Tidak terdapat ada interaksi antara model guided inquiry learning dan 
digital learning terhadap kemampuan storytelling mahasiswa.

\section{DAFTAR PUSTAKA}

Aliyah, S. (2011).Pengaruh Metode Storytelling dengan Media PanggungBoneka terhadap Peningkatan Kemampuan Menyimak dan Berbicara AnakUsia Dini.(Tesis). Sekolah Pasca Sarjana, UPI, Bandung

Asfandiyar, Andi Yudha, 2007. Cara Pintar Mendongeng, Jakarta: Mizan.

Bilgin, I. (2009). The Effect of Guided Inquiry Instruction Incorporating Cooperative Learning Approach on University students' Achievement of Acid and Based Concepts and Attitude Toward Guided Inquiry Instruction.

Scientific Research and Essay.Volume 4.No. 10. Pp 1038-1046. Turki

Douglas, dkk.(2009). Use of Guided Inquiry as an active learning technique

in engineering.Proceeding of the Research in engineering education

symposium, hlm 1-6

Fathurrohman, M. 2015. ModelModel Pembelajaran Inovatif. Editor Nurhidayah. Cetakan I

Penerbit Ar-Ruzz Media. Jogjakarta

Greene, Ellin, 1996. Storytelling Art\&Technique, United States of America: Reed Elsevier.

Huda, Miftahul. 2014. Model-Model Pengajaran dan Pembelajaran: Isu-Isu

Metodis dan Paradigmatis. Yogyakarta: Pustaka Pelajar.

Kusmayadi, Ismail. 2008. "Think
Smart Bahasa Indonesia”. Bandung Grafindo Media Pratama.

Lodia Johanis (2015), Penerapan Model Guided Inquiry Untuk Meningkatkan Hasil Belajar Mahasiswa Ambon, Konsep Sistem Pernapasan Manusia Kelas XI SMA Negeri 12 Ambon Manalu, $\quad$ Effendi. 2014. Meningkatkan Kreativitas Bercerita Siswa Melalui Model Pembelajaran Paired Story Telling pada Mata Pelajaran Bahasa Indonesia Di Kelas VI SDN Sei Renggas. Terdapat di http://jurnal.unimed.ac.id/2012/i ndex.php/school/article/downloa d/1696/1378.

Diunduh tanggal 25 Agustus 2017.

Mohamad Nur, dkk (2014), Penggunaan Metode Inquiri Terbimbing Untuk Meningkatkan Hasil Belajar Mahasiswa Pada Pokok Bahasan Tumbuhan Hijau di Kelas V SDN 2 Bora

Priyatno., 2011. Buku Saku SPSS Analisis Statistik Data (lebih Cepat, Efisien dan Akurat). Penerbit Mediakom. Yogyakarta Purwant. 2011. Evaluasi Hasil Belajar. Yogyakarta: Pustaka Belajar

Sugiono., 2010. Metode Penelitian Pendidikan Pendekatan Kuantitatif, Kualitatif danR\&D. Penerbit Alfabeta. Bandung

Tom Vander Ark \& Carri Schneder (2012), How Digital Learning to Deeper Learning

Vivone.dkk. (2004).Focus On Inquiry: A Teacher's Guide To Implementing

Inquiry-Based Learning. Canada: Alberta Learning 